\title{
Correction to: Targeting TR4 nuclear receptor suppresses prostate cancer invasion via reduction of infiltrating acrophages with alteration of the TIMP-1/ MMP2/MMP9 signals
}

\author{
Xianfan Ding ${ }^{1,2 \dagger}$, Dong-Rong Yang ${ }^{2,3 \dagger}$, Liqun Xia ${ }^{1 \dagger}$, Bide Chen ${ }^{1}$, Shicheng $\mathrm{Yu}^{1}$, Yuanjie Niư ${ }^{4}$, Mingchao Wang ${ }^{1}$, \\ Gonghui Li ${ }^{*}$ and Chawnshang Chang ${ }^{2,5^{*}}$
}

Correction to: Mol Cancer (2015) 14:16

https://doi.org/10.1186/s12943-014-0281-1

Following the publication of the original article [1], the corresponding author recently found error in the Fig. 2A. Below is the corrected image. This error could be due to mislabel and/or incorrect insertion during transfer of numerous images between computers in two countries after he returned from USA and became occupied with his university work to establish a laboratory. They assure that the correction of this image will not alter the conclusion of the results. The authors are appreciative for the publication of this correction paper.
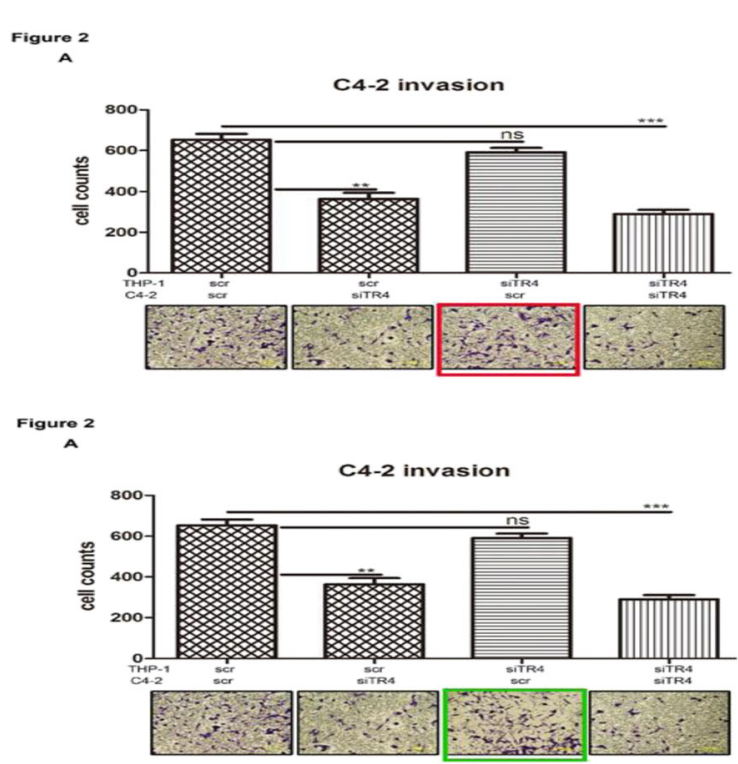

The original article can be found online at https://doi.org/10.1186/s12943014-0281-1.

* Correspondence: ligonghui1970@hotmail.com; chang@urmc.rochester.edu

+Xianfan Ding, Dong-Rong Yang and Liqun Xia contributed equally to this work.

${ }^{1}$ Department of Urology and Chawnshang Chang Liver Cancer Center, Sir Run Run Shaw Hospital, School of Medicine, Zhejiang University, Hangzhou 310016, China

${ }^{2}$ George Whipple Lab for Cancer Research, Departments of Pathology,

Urology and Radiation Oncology, and The Wilmot Cancer Center, University of Rochester Medical Center, Rochester, NY 14646, USA

Full list of author information is available at the end of the article

(c) The Author(s). 2020 Open Access This article is licensed under a Creative Commons Attribution 4.0 International License, which permits use, sharing, adaptation, distribution and reproduction in any medium or format, as long as you give appropriate credit to the original author(s) and the source, provide a link to the Creative Commons licence, and indicate if changes were made. The images or other third party material in this article are included in the article's Creative Commons licence, unless indicated otherwise in a credit line to the material. If material is not included in the article's Creative Commons licence and your intended use is not permitted by statutory regulation or exceeds the permitted use, you will need to obtain permission directly from the copyright holder. To view a copy of this licence, visit http://creativecommons.org/licenses/by/4.0/ The Creative Commons Public Domain Dedication waiver (http://creativecommons.org/publicdomain/zero/1.0/) applies to the data made available in this article, unless otherwise stated in a credit line to the data. 


\section{Author details}

'Department of Urology and Chawnshang Chang Liver Cancer Center, Sir Run Run Shaw Hospital, School of Medicine, Zhejiang University, Hangzhou 310016, China. ${ }^{2}$ George Whipple Lab for Cancer Research, Departments of Pathology, Urology and Radiation Oncology, and The Wilmot Cancer Center, University of Rochester Medical Center, Rochester, NY 14646, USA.

${ }^{3}$ Department of Urology, the 2nd Affiliated Hospital of Soochow University, Suzhou 215004, China. ${ }^{4}$ Chawnshang Chang Sex Hormone Research Center Tianjin Institute of Urology, Tianjin Medical University, Tianjin 300211, China. ${ }^{5}$ Sex Hormone Research Center, China Medical University/Hospital, Taichung 404, Taiwan.

Published online: 30 May 2020

\section{Reference}

1. Ding X, Yang D-R, Xia L, Chen B, Yu S, Niu Y, Wang M, Li G, Chang C. Targeting TR4 nuclear receptor suppresses prostate cancer invasion via reduction of infiltrating acrophages with alteration of the TIMP-1/MMP2/ MMP9 signals. Mol Cancer. 2015;14:16. https://doi.org/10.1186/s12943-0140281-1. 